\title{
PEMBERIAN ARANG AKTIF, ZEOLIT, DAN MANGANESE GREENSAND TERHADAP KELANGSUNGAN HIDUP Oreochromis niloticus PADA SISTEM TRANSPORTASI
}

\section{SURVIVAL RATE OF Oreochromis niloticus IN TRANSPORTATION SYSTEM BY ACTIVATED CHARCOAL, MANGANESE GREENSAND AND ZEOLITE}

\author{
Mahendra $^{1 *}$, Fazril Saputra ${ }^{1}$, Citra Dina Febrina ${ }^{1}$, Yusran Ibrahim ${ }^{1}$, Farah Diana ${ }^{1}$, Sufal \\ Diansyah $^{1}$ \\ ${ }^{1}$ Program Studi Akuakultur, Fakultas Perikanan dan Ilmu Kelautan Universitas Teuku Umar, \\ Meulaboh \\ *Korespondensi: mahendra@utu.ac.id
}

\begin{abstract}
This study aims to determine the effect of administration of activated charcoal, zeolite, and manganese greensand on survival Oreochromis niloticus. The experimental design used was a completely randomized design (CRD) with 4 treatments and 3 repetitions. The treatments are $P 1=$ without administration (control), $P 2=$ administration of activated charcoal $10 \mathrm{gr} / \mathrm{P3}=$ administration of Zeolite $10 \mathrm{gr} / \mathrm{l}$ and $\mathrm{P} 4$ = administration of manganese $10 \mathrm{gr} / \mathrm{l}$. The parameter observed in this study was survival Oreochromis niloticus. The results showed that administration of activated charcoal, zeolites, and manganese greensand significantly affected the survival of Oreochromis niloticus. The best value is obtained at treatment P1; P2; and P3, each with the best average survival value of 96\%; 91\%; and 91\%. The lowest cost incurred is the treatment P1 Rp. 66.200, - with SR $96 \%$ transportation.
\end{abstract}

Keywords: Transportation system, Oreochromis niloticus, Survival rate

\section{Pendahuluan}

Ikan Oreochromis niloticus adalah ikan air tawar yang mempunyai peluang untuk dibudidayakan secara komersial, selain budidaya cukup mudah, ikan Oreochromis niloticus mempunyai pertumbuhan yang cepat serta penyesuaian lingkungan cukup baik. Ketersediaan benih dan penyebaran benih dari satu tempat ke tempat yang lain merupakan beberapa permasalahan dalam budidaya ikan Oreochromis niloticus. Permasalahan yang sering dihadapi oleh petani Indonesia dalam pengiriman benih Oreochromis niloticus adalah sintasan (SR) yang rendah akibat perubahan mutu air selama pengangkutan antara lain: tingginya kadar $\mathrm{CO} 2$, akumulasi amoniak, rendahnya $\mathrm{O}_{2}$ (Maraja et al., 2017).

Transportasi ikan hidup dapat diartikan sebagai suatu tindakan memindahkan ikan dalam keadaan hidup dari suatu tempat ke tempat lain yang di dalamnya diberi tindakan-tindakan untuk menjaga agar derajat kelangsungan hidup ikan tetap tinggi hingga ke tempat tujuan. Penggunaan Transportasi ikan hidup biasanya dilakukan untuk menjamin semua aktivitas seperti metabolisme dan 
respirasi tetap berjalan normal dalam ransportasi jarak jauh. Dari segi efisiensi pengangkutan, sistem ini memiliki kelemahan yaitu air yang digunakan sebagai media memberikan tambahan beban selama transportasi serta kualitas air juga harus terjaga (Nani et al., 2015).

Salah satu usaha yang dilakukan untuk menetralisir amoniak adalah dengan cara menambahkan zeolit dan karbon aktif di dalam media transportasi (Choironawati, 2012). Zeolit mempunyai kemampuan menyerap ion NH4 atau ion-ion lainnya sedangkan karbon aktif merupakan suatu bentuk karbon yang mempunyai sifat adsorbtif terhadap suatu larutan, gas, atau uap (Humairani et al., 2016). Serta manganese greensand yang juga sama seperti zeolit yang mampu menyerap ion NH4 (Said, 2005). Penelitian ini bertujuan untuk menentukan efektivitas penambahan karbon aktif, zeolit dan manganese greensand dalam mempertahankan kualitas air pada pengangkutan tertutup sehingga dapat meminimalisir tingkat kematian Oreochromis niloticus yang diangkut selama 24 jam dan kondisi fisiologi udang pascatransportasi tetap baik.

\section{Motode Penelitian}

\section{Waktu dan Tempat}

Penelitian ini telah dilakukan di hatchary Fakultas Perikanan dan Ilmu Kelautan Universitas Teuku Umar Meulaboh pada bulan Oktober.

\section{Bahan dan Alat}

Bahan yang digunakan pada penelitian ini yaitu Oreochromis niloticus ukuran konsumsi, garam, dan plastik packing berukuran 40x60 cm yang salah satu ujung plastik diikatkan (Ismi, 2017), zeolite,karbon aktif dan manganese greensand. Wadah yang digunakan pada saat pemeliharaan ikan pasca transportasi yaitu akuarium berukuran $100 \times 50$ x $50 \mathrm{~cm}$.

\section{Rancangan penelitian}

Metode yang digunakan dalam penelitian ini adalah metode eksperimen dan rancangan yang digunakan adalah Rancangan Acak Lengkap (RAL) yang terdiri dari 4 perlakuan dengan masing-masing 3 kali ulangan. Perlakuan masing-masing bahan yang digunakan dalam penelitian ini meliputi:

$\mathrm{P} 0=$ tanpa perlakuan bahan (kontrol)

$\mathrm{P} 1=$ pemberian arang aktif $10 \mathrm{gr} / 1$

$\mathrm{P} 2$ = pemberian Zeolit $10 \mathrm{gr} / 1$

$\mathrm{P} 3=$ pemberian manganese $10 \mathrm{gr} / 1$

\section{Prosedur Penelitian}

Wadah disiapkan terlebih dahulu berupa Akuarium sebanyak 15 liter untuk penempatan ikan. Kemudian ikan ditangkap dengan menggunakan serok/seser yang sudah ditimbang bobotnya, setelah ditimbang ikan dimasukkan ke dalam plastic packing sebanyak 15 ekor/kantong (Bayhaqi, 2016), kemudian 
memasukkan bahan berupa arang aktif, zeolite dan manganese greensand sesuai dosis perlakuan. Setiap perlakuan ditambahkan garam untuk mempertahankan metabolisme ikan (Pamungkas, 2010; Ginting, 2012). Mengikat kantong plastik menggunakan karet. Memasukkan kantong plastik ke dalam sterofoam Memasukkan es batu di selah-selah kantong plastik packing. Transportasi menggunakan jalur darat selama kurang lebih 3 jam perjalanan dan sesampainya dilokasi tujuan dibiarkan selama 24 jam (Hapsari, 2014)

\section{Variable yang diamati}

Kelangsungan hidup

Kelangsungan hidup menurut Mahendra dan Rizal (2019), dihitung dengan rumus sebagai berikut:

$$
\mathrm{SR}=\mathrm{Nt} / \mathrm{No} \times 100 \%
$$

Keterangan :

SR : Kelangsungan hidup (\%)

Nt : Jumlah ikan pada waktu $\mathrm{t}$ (individu)

No : Jumlah ikan pada awal percobaan (individu)

\section{Analisis Keuntungan}

Variable yang diamati lainnya adalah analisis keuntungan untuk perhitungan biaya transportasi ikan. Analisis keuntungan dilihat dari biaya yang dikeluarkan selama penelitian berlangsung.

\section{Analisis Data}

Data yang diperoleh akan dikelompokkan, ditabulasikan, dilakukan uji statistik ANOVA dan SPSS untuk melihat pengaruh percobaan. Jika terdapat perbedaan yang sinifikan, akan dilakukan uji lanjut BNT (Mahendra dan Supriadi, 2019).

\section{Hasil Dan Pembahasan \\ Kelangsungan hidup}

Hasil yang diperoleh pada penelitian ini (Gambar 1) menunjukkan bahwa tingkat kelangsungan hidup yang terbaik adalah pada perlakuan P1; P2; dan P3 yang mencapai nilai masing-masing $96 \%$; 91\%; dan 91\%. Sedangkan kelangsungan hidup terendah terjadi pada perlakuan P1 (tanpa penambahan/kontrol) dengan nilai 58\%. Tingkat kelangsungan hidup yang rendah dikarenakan selama transportasi ikan melakukan berbagai aktivitas seperti respirasi dan metabolisme lainnya seperti ekskresi feses sehingga terdapat amoniak yang dapat membahayakan fisiologi tubuh ikan. Menurut Choironawati, (2012) menambahkan beberapa hal penyebab kematian ikan dalam transportasi seperti menipisnya persediaan oksigen terlarut di media transportasi, akumulasi dari gas toksik seperti amoniak, luka fisik akibat penanganan sebelum 
transportasi, gerakan ikan yang hiperaktif di awal transportasi, fluktuasi suhu air yang mendadak, dan penyakit.

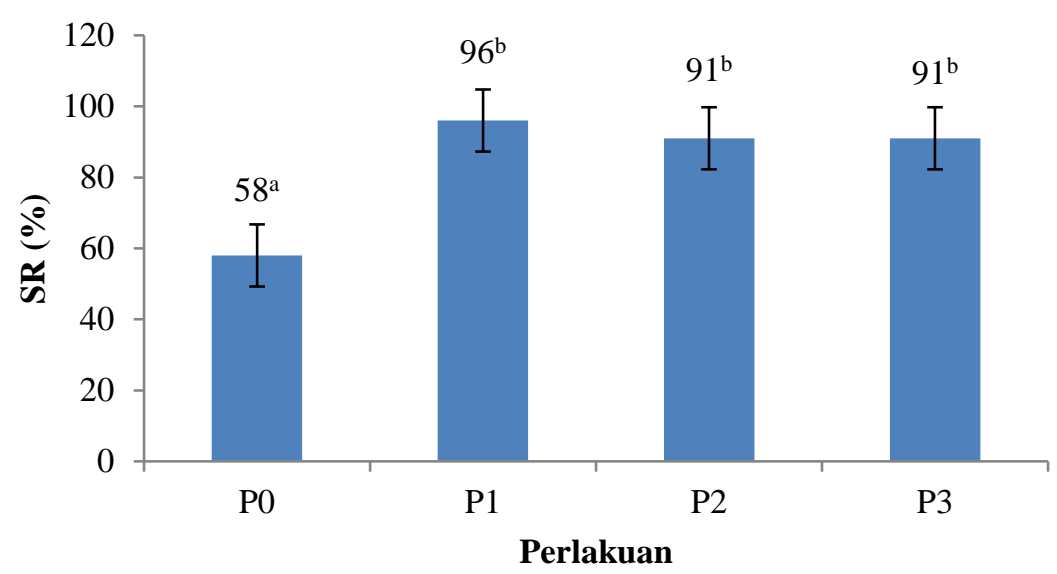

Gambar 1. Kelangsungan Hidup Oreochromis niloticus

Penambahan bahan aktif ke dalam media transportasi mempengaruhi tingkat kelangsungan hidup ikan. Berdasarkan hasil yang diperoleh, diketahui tingkat kelangsungan hidup ikan selama transportasi dipengaruhi oleh kualitas air di dalam media dan adanya peran penambahan bahan kedalam media yaitu zeolit, karbon aktif, dan manganese greensand. Penambahan zeolit dalam transportasi ikan adalah sebagai penukar ion $\mathrm{NH}_{4}$ atau ion-ion lainnya. Sehingga dapat menetralkan racun hasil metabolisme. Hal ini sesuai dengan Choironawati (2012), bahwa zeolit dapat menjerap molekul polar dengan selektifitas yang tinggi dan $\mathrm{CO}_{2}$ merupakan salah satu molekul polar sedangkan karbon aktif memiliki sifat absorbtif terhadap suatu larutan, gas, atau uap sehingga bahan tersebut dapat digunakan sebagai penjernih larutan, penghisap gas atau racun dan penghilang warna. Sifat karbon aktif yang paling penting adalah daya serap. Banyak senyawa yang dapat diabsorpsi oleh karbon aktif, tetapi kemampuannya untuk mengabsorpsi berbeda untuk masing-masing senyawa (Humairani et al., 2016). Penambahan manganese greensand juga sama seperti zeolit yang mampu menyerap ion NH4 (Said, 2005).

\section{Analisis Keuntungan}

Berikut ini merupakan analisa efisiensi biaya transportasi benih ikan nila satu kantong dengan kepadatan 15 ekor/kantong.

Tabel 1. Perhitungan Pembiayaan Transportasi Benih Ikan Nila

\begin{tabular}{llcccccc}
\hline \multirow{2}{*}{ Jenis Biaya } & Satuan & \multirow{2}{*}{\begin{tabular}{c}
\multirow{2}{*}{$\begin{array}{c}\text { Hah } \\
\text { lah }\end{array}$} \\
\cline { 5 - 7 }
\end{tabular}} & $\begin{array}{c}\text { an } \\
(\mathrm{Rp})\end{array}$ & $\begin{array}{c}\text { Tanpa } \\
\text { bahan }\end{array}$ & $\begin{array}{c}\text { Arang } \\
\text { aktif }\end{array}$ & zeolit & $\begin{array}{c}\text { Manganese } \\
\text { greensand }\end{array}$ \\
\hline $\begin{array}{l}\text { Ikan nila } \\
\begin{array}{l}\text { Oksigen } \\
\text { murni per }\end{array}\end{array}$ & $\begin{array}{l}\text { Rp/ekor } \\
\text { Rp/kg }\end{array}$ & 60 & 1.500 & 90.000 & 90.000 & 90.000 & 90.000 \\
kantong & & 4 & 5.000 & 20.000 & 20.000 & 20.000 & 20.000 \\
& & & & & & &
\end{tabular}




\begin{tabular}{|c|c|c|c|c|c|c|c|}
\hline $\begin{array}{l}\text { Plastic } \\
\text { packing }\end{array}$ & $\begin{array}{l}\text { Rp/lemb } \\
\text { ar }\end{array}$ & 8 & 2.000 & 16.000 & 16.000 & 16.000 & 16.000 \\
\hline $\begin{array}{l}\text { Transportasi } \\
\text { per packing }\end{array}$ & $\begin{array}{l}\text { Rp/kanto } \\
\text { ng }\end{array}$ & 4 & 5.000 & 20.000 & 20.000 & 20.000 & 20.000 \\
\hline percobaan & Rp/gram & & 12 & & & & \\
\hline Arang & & 600 & 5 & 0 & 7.200 & 3.000 & 10.800 \\
\hline Zeolite & & & 18 & & & & \\
\hline Mangan & & & & & & & \\
\hline \multicolumn{4}{|c|}{ Total Biaya } & 146.000 & 153.200 & 149.000 & 156.800 \\
\hline \multicolumn{4}{|c|}{ SR Transportasi } & $58 \%$ & $96 \%$ & $91 \%$ & $91 \%$ \\
\hline \multicolumn{4}{|c|}{ Analisis Pembiayaan } & 93.500 & 66.200 & 66.500 & 74.300 \\
\hline
\end{tabular}

Biaya terendah yang dikeluarkan yaitu pada perlakuan P1 (arang aktif) sebesar Rp. 66.200,- dengan kelangsungan hidup (SR) transportasi 96\% dan tertinggi pada perlakuan P0 (tanpa perlakuan) sebesar Rp. 93.500,- dengan kelangsungan hidup (SR) transportasi 58\%.

Transportasi merupakan salah satu rangkaian siklus produksi yang bersifat ekonomi yaitu dalam hal distribusi (Choironawati, 2012). Perhitungan biaya transportasi benih ikan nila dengan perlakuan penambahan bahan percobaan arang aktif, zeolit dan manganese greensand diperoleh efisiensi biaya yang berbeda untuk setiap perlakuan. Biaya terendah yang dikeluarkan yaitu pada perlakuan P1 (arang aktif) sebesar Rp. 66.200,- dengan kelangsungan hidup (SR) transportasi 96\% dan tertinggi pada perlakuan P0 (tanpa perlakuan) sebesar Rp. 93.500,dengan kelangsungan hidup (SR) transportasi 58\% (Tabel 1). Perlakuan P1 (arang aktif) menghasilkan biaya yang paling murah dikarenakan jumlah ikan hidup yang lebih banyak daripada perlakuan lainnya. Semakin banyak benih ikan yang bertahan hidup maka semakin murah pula biaya pengiriman dan semakin banyak keuntungan yang diperoleh. Meskipun harga arang aktif lebih tinggi (Rp.7.200) di bandingkan harga zeolite (Rp. 3.000), efisiensi biaya tetap lebih baik arang aktif karena jumlah ikan hidup yang lebih banyak daripada menggunakan bahan zeolit

\section{Kesimpulan}

Adapun kesimpulan dalam penelitian ini adalah pemberian arang aktif, zeolit dan manganese greensand berpengaruh nyata terhadap kelangsungan hidup ikan Oreochromis niloticus. Perlakuan terbaik untuk kelangsungan hidup ikan Oreochromis niloticus terdapat pada perlakuan P1; P2; dan P3 yaitu masingmasing dengan nilai rata-rata terbaik adalah $96 \%$; 91\%; dan $91 \%$.

\section{Daftar Pustaka}

Bayhaqi A. 2016. Peranan Minyak Cengkeh (Eugenia aromatica) Pada Transportasi Tertutup Benih Ikan Bandeng (Chanos chanos). Thesis, Universitas Muhammadiyah Gresik.

Choironawati AI. 2012. Pemanfaatan Zeolit Dan Karbon Aktif Dalam Transportasi Tertutup Benih Ikan Nila Best Oreochromis sp. Dengan Kadar Garam Berbeda. Skripsi. Institut Pertanian Bogor. 
Ginting MSA. 2012. Efektivitas Penambahan Garam Dalam Media Transportasi Tertutup Benih Ikan Gurame Osphronemus gouramy Lac. Skripsi. Institut Pertanian Bogor.

Hapsari AY. 2014. Efektivitas Penambahan Zeolit $20 \mathrm{~g} / \ell$, Karbon Aktif $10 \mathrm{~g} / \ell$ dan Garam $5 \mathrm{~g} / \ell$ Dalam Transportasi Tertutup Benih Ikan Gurame Osphronemus goramy Lac dengan Kepadatan Berbeda. Skripsi. Institut Pertanian Bogor.

Humairani, Supriyono E, dan Nirmala K. 2016. Penambahan Zeolit, Karbon Aktif, Minyak Cengkeh, Dan Salinitas Yang Berbeda Terhadap Respon Glukosa, Tingkat Kerja Osmotik Dan Histologi Benih Udang Galah Pada Simulasi Transportasi Tertutup Dengan Kepadatan Tinggi. Jurnal Ilmu dan Teknologi Kelautan Tropis 8(1): 215-226.

Ismi S. 2017. Pengaruh Penggantian Oksigen Pada Transportasi Benih Kerapu Dengan Sistem Tertutup. Jurnal Ilmu dan Teknologi Kelautan Tropis 9(1): 385-391.

Mahendra dan Supriadi. 2019. Laju Pertumbuhan Larva Ikan Seurukan (Osteochilus vittatus) Dengan Pemberian Kuning Telur Unggas. Jurnal Akuakultura 3(1): 13-20.

Mahendra dan Rizal M. 2019. The Growth and Efficiency of Galah Shrimp Feed (Macrobrachium Rosenbergii De Man) with the Addition of Caffeine in Commercial Feed. Budapest International Research in Exact Sciences (BirEx) Journal 1(4): 112-120.

Maraja MK, Salindeho N, dan Pongoh J. 2017. Penanganan Ikan Nila (Oreochromis niloticus) Hidup Dengan Menggunakan Es Sebagai Pengawet. Jurnal Media Teknologi Hasil Perikanan 5(3): 174 - 179.

Nani M, Abidin Z, dan Setyono BDH. 2015. Efektivitas Sistem Pengangkutan Ikan Nila (Oreochromis Sp) Ukuran Konsumsi Menggunakan Sistem Basah, Semi Basah Dan Kering. Jurnal Akuakultur Rawa Indonesia 3(2): 84-90.

Pamungkas TR. 2010. Efektivitas Penambahan Zeolit, Karbon Aktif, Minyak Cengkeh, Dan Garam Dalam Transportasi Tertutup Benih Ikan Patin Pangasionodon hypopthalmus Dengan Kepadatan Berbeda. Skripsi. Institut Pertanian Bogor.

Said N. 2005. Metoda Penghilangan Zat Besi Dan Mangan Di Dalam Penyediaan Air Minum Domestik. Jurnal Akuakultur Indonesia (3): 239 - 250. 